\title{
Geopolitical and logistical factors in the evolution of North Korea's shipping flows
}

\author{
César DUCRUET, Sung-Woo LEE, Stanislas ROUSSIN
}

Pre-final version of the chapter published in Ducruet C. (Ed.) (2017) Advances in Shipping Data Analysis and Modeling. Tracking and Mapping Maritime Flows in the Age of Big Data, Routledge Studies in Transport Analysis, pp. 357-379.

Traditionally in socialist economies, maritime transport has been considered costly and useless, its role being often limited to coastal shipping within the socialist block (Vigarié, 1995). Nevertheless, North Korea possesses and operates eight international trading ports located along two maritime façades, which directly connect its major cities with international trade. North Korean ports are the potential gateways for a Eurasian land bridge (Choi et al., 2003; Rozman, 2004). Internally, coastal shipping may remedy the growing logistical difficulties caused by a prolonged economic crisis. Maritime transport remains the principal vector of inter-Korean economic exchange with $90 \%$ of commercial relationships ensured by sea (Kim, 2001; Olsen et al., 2003). Studying North Korea's shipping flows thus presents numerous challenges for academic research in both conceptual and empirical terms. How does a major and deepening economic and geopolitical crisis impact the pattern and evolution of shipping flows? What are the respective roles of internal and external factors? (see Chapters 6, 10, and 20 on Portugal, USA, and China for other analyses of external linkages of national port systems, and Chapters 8 and 19 on the link between shipping flows and socialist economies).

The fact that even an ostensibly closed country like North Korea is fully part of a global system for recording vessel movement means that such questions do not go unanswered. The majority of North Korean vessels are insured in London by Lloyd's Register (Smith, 2009); thus, vessel movement at North Korean ports has been surveyed for decades, although it is only recently that such information has served economic and geographic analyses and offset the lacks and deficiencies of data on North Korea as a whole (Noland, 2000; Nanto and Chanlett-Avery, 2005) by looking at the changing distribution and concentration of maritime flows internally and with the rest of the world (Ducruet et al., 2009).

This chapter proposes to update and extend previous analyses by expanding the time period, from the early twentieth century to the year 2015, for which shipping data has recently 
become available. Vessel calls at North Korean ports were measured across different units and time periods, either through a simple count based on the Shipping Index (1905-2008) or on their tonnage weight and spatial distribution (1977-2015) using digital information from Lloyd's List Intelligence. We systematically confront traffic trends with general (and often limited) knowledge of transport and trade characteristics gathered from field observation and official, second-hand information sources. This will help us to better understand the origin and ultimate development of maritime transport in the North Korean economy, through the successive phases of Korean unity, Japanese colonization, war and partition, Cold War growth and Soviet support, isolation, decline, and Chinese influence.

The second section of the chapter provides a historical background on ports, transport, and economic development in the light of contemporary political changes. It also presents new results on traffic evolution at North Korean ports from various angles, such as fleet nationality and performance. The third section investigates the importance of maritime transport in the North Korean economy. Lastly, we analyse the changing distribution of overseas linkages, with a specific focus on shipping flows between the Koreas and with China.

\section{The North Korean port system}

There is evidence that ports in North Korea have been operating since the Three Kingdoms and Goryeo era (37BC-1392AD). In particular during the Balhae Kingdom (698-934), shipping routes existed between Seoanpyeong (Amnok River) and the Shandong Peninsula in China; between Yeomju (current Russia) and Namgyeong with Japan. Under the Goyeo period, Seogyeong (currently Pyongyang) was well connected with China. Later on, the Korean fleet became the most important on the Yellow Sea, frequently trading with Arab merchants along the Yaeseong River near the then capital city, Gaeseong. Before the Manchu invasions, sea transport was promoted by the government, which even planned to build a national fleet around 1402, before letting private interests do so after 1529 , due to the related cost and labor issues. In that period, ports in North Korea remain less connected to main trade routes, except from Wonsan, which connects the East coast with southern Siberia. The Choseon era (1392-1910) is mainly characterized by the decline of maritime trade, due to Manchu invasions, China's confucianist preference for landward development and growing Japanese pressure on the construction and modernization of North Korean ports before the 1910 invasion and colonial rule. Investments particularly concentrated at Nampo, Haeju, Yongampo-Sinuiju, Wonsan (with the British) but also Incheon and Busan in the South, while the Japanese created the rail link Seoul-Wonsan in 1904, buying the rights from the British but also from the French (Seoul-Sinuiju). After the Japanese and Manchu invasions, several ports kept a domectic role only, such as Hwangju (south of Pyongyang), Wonsan, Yongampo 
(Amnok River), and Cheongjin. While shipping activity in North Korea (and Korea as a whole) does not appear in Lloyd's Shipping Index before 1905, it provides us with a long-term view over the last century (Figure 21.1).

[Figure 21.1]

Under Japanese rule (1910-1945), the northern part of the Korean Peninsula became the prime focus of Japan's strategy to conquer Manchuria, with investments in railways, mining (purchasing rights from the US or UK), ports, and factories. During the Korean War (19501953), many port sites were heavily damaged if not entirely destroyed. While North Korea managed to overcome such a disaster and become East Asia's second most industrialized nation in the 1960s after Japan, its dynamism faltered in the 1970s and started to collapse in the 1980s. The 1961 seven-year Development Plan with its strong focus on maritime transport and foreign trade had somewhat limited effects (Ahn, 2003) due to the reliance, during the Cold War, on Soviet and Chinese support (Cotton, 1996). Ports received little investment apart from the creation of Rajin port in 1974 and some oil berths and storage facilities. A move towards openness started in 1984, with the opening of the Rajin-Seonbong (Raseon) free-trade zone in 1991 (Jo and Ducruet, 2007). However, the collapse of the Soviet Union (1989-1993) and the Socialist Block immediately resulted in the loss of North Korea's main trading partners and the lack of capital to purchase hydrocarbons on international markets, resulting in traffic decline.

Subsequently, factories ceased to operate, mines were flooded, transport became paralyzed, and agricultural productivity declined without sufficient fertilizers and mechanization, aggravated by natural disasters (1994-1995) and the three-year vacancy at the head of the State after the death of President Kim II-Seong (1994). US-North-Korean tensions rose over Pyongyang's nuclear program, leading to an internal policy more and more centred on the Army as a reaction against the Wassenaar Agreement (1996), restraining exports and controlling the importation of technological goods. Limited foreign trade and the deterioration of infrastructure and capital stock (Yoon and Babson, 2002) persisted until the agricultural reforms of 1998, the June 2000 inter-Korean summit, and the July 2002 reforms, which conferred certain autonomy to businesses, and led to improved labor welfare, and commercial distribution (e.g. Pyeonghwa Automobiles), and the development of factories, farms and private businesses. One important factor had also been to become able to purchase oil, giving a small boost to the economy. Despite the failure of the Special Administrative Region (SAR) of Sinuiju in 2002, a number of economic development projects grew rapidly, such as the International Tourism Zone of Mount Geumgang (1999), and the Gaeseong Industrial Complex (2004) financed by South Korea. Such initiatives, in addition to the development by the army of hydro power plants, housing, and highways, helped compensate for the decline of the industrial sector (Ahn, 2003), However, despite its 
numerous advantages over China in terms of labour force and natural resources (Roussin, 2015), North Korea's appeal for the international business community continuously decreased (Lee, 2005). The devastation in the manufacturing and transport sector was such that only $20 \%$ of factories remained operational, with energy production meeting only 30 $50 \%$ of the country's needs, and companies spending about $40 \%$ of their manufacturing costs on logistics (Foster-Carter, 2001). The priority given to railways and heavy industries, combined with poor technical standards and cumbersome customs regulations, resulted in prolonged shipping time (Ahn, 2002), a lack of modern cargo-handling facilities (Kim, 2001), exorbitant port-entry fees and $45 \%$ of containers returning empty (Foster-Carter, 2001). Certain containers even disappear or are changed into hangars or lodging boxes. Port modernization mainly occurred thanks to Chinese and Russian support, such as in Nampo and Rajin (Jo and Ducruet, 2006), leading to greater accessibility and a boost to transit trade, but for the external interests of Russia and China.

\section{Traffic dynamics of North Korean ports}

\section{Domestic versus foreign fleet traffic}

As referred to by Smith (2009) based on Lloyd's Register 2008 data, the vast majority of North Korean vessels are general cargo ships (53\%) and fishing vessels (24\%), followed by some oil tankers and bulk carriers. The same report also underlined its ageing and limited capacity, the fragmentation of ownership, and the majority of vessels being flagged at home. It was possible to verify a number of traffic dynamics based on daily vessel movement data. Based on Figure 21.2, one can observe significant traffic fluctuations over the period, with a noticeable decline from the 1980s to the 2000s until a recent but timid recovery. Following regular traffic growth until 1987, the economy started to falter before the Soviet Union collapsed. Certain exceptions can be observed, such as the effects of the Rajin-Seonbong free-trade zone (1991-1992), humanitarian aid, economic reforms, the KEDO project, and inter-Korean cooperation (1999-2002), the inter-Korean maritime agreement (2004-2005), and growing trade with China (2014-2015).

[Figure 21.2]

Disaggregating traffic figures according to vessel flags, -North Korean or foreign - allows us to further understand the technical evolution of the domestic fleet as well as North Korea's level of reliance upon other fleets (Figure 21.3). As such, foreign traffic concentrated more than $70 \%$ of the total traffic on average, but with different phases: $85 \%$ in $1977-1984 ; 70 \%$ in 1985-1992; 57\% between 1993-2002 (under 50\% in 1996-1998); and 80\% in 2003-2015. Yet 
in absolute terms, foreign traffic has registered a constant decline since the mid-1980s. By comparison, traffic under the North Korean flag remained somewhat stable between 1984 and 2002. This may be explained by the use of naval ships for commercial purposes in emergencies. Trains that were responsible for most landward communications got paralyzed by the lack of electricity, most of the railway network being electrified.

In terms of average vessel size, foreign traffic largely dominated, except in 1984, 1997, and 2004-2009, while both foreign and domestic vessels have regularly reduced over time, due to falling demand, accessibility issues and a deterioration in cargo-handling equipment. In addition, larger ships that are costlier to repair and operate tend to disappear over time, as North Korea lacks sufficient capital or shipbuilding facilities to maintain and modernize its fleet. The exception of 1999-2002 for foreign vessels relates to humanitarian support. Vessel sizes also reflect wider issues, such as the missile crisis with Japan (1998) and the levy of sanctions by Washington in 1999. The sudden decline in 2002 marks an end to oil shipments from the United States, Japan, and the European Union due to Pyongyang's suspected uranium enrichment program. The upward turn in 2005 could reflect the impact of the interKorean agreement that liberalized the movement of vessels between North and South. From 2008-2009, the average vessel size for both fleets grew once again despite low cargo volumes.

[Figure 21.3]

The analysis of turnaround times (Figure 21.4) by fleet, excluding a few exceptional stays lasting more than one year, is based on the average time difference between arrival date and sailing date for each call at North Korean ports. Without exception, North Korean ships stayed longer in ports than foreign ships, partly due to the "home effect". Maritime transport by sea often constituted a secondary option compared with overland (crossborder). Despite inspection and bureaucratic procedures affecting foreign ships, the latter witnessed a growing turnaround time gap compared with the domestic fleet from the 1990s onwards. The reduction and disappearance of former trade routes deprived North Korean ships of their activity, which was aggravated by the lack of fuel supplies. Thus, the majority remained anchored at their home terminals, until the situation improved from 2000 onwards, although important delays at North Korean ports were regularly reported in the press, most cargoes being handled by hand. The peak of 2005 marks North Korea's very unstable attitude in relation to humanitarian organizations and nuclear talks with other nations. Nevertheless, a decrease in turnaround times for foreign ships also suggests greater flexibility in the management of North Korean ports through less cumbersome regulations.

[Figure 21.4] 
In terms of fleet age, North Korean vessels have always been older than foreign vessels except in the period 1977-1984. From 1985 onwards, domestic and foreign fleets followed a similar trend, but from 1997 North Korean vessels aged more rapidly and foreign vessels stabilized. The average age of foreign ships was 15 years, compared with 18 for the North Korean fleet, while the average age per ship for fleets from developing countries was around 14 years (see UNCTAD, 2000). Due to the crisis in the North Korean shipbuilding sector since the mid-1980s most of the currently operated vessels were constructed before 1984. Again, the impact of the mid-1990s crisis is clearly visible, North Korea being forced to push the fleet to its limits to palliate deficiencies in the wider transport system. As a result, Japanese authorities banned North Korean ships from their ports on the grounds of technical and hygiene issues (Lloyd's Register, 2004). Thus, while North Korean vessels were aged 14 years on average between 1977 and 1996, this had increased to 23 between 1997 and 2015, compared with 13 and 17 years for foreign vessels for the respective periods.

\section{Shipping and trade}

Traditionally in North Korea, inland transportation has dominated the modal split, as a longterm effect of Japanese occupation (1910-1945) and of the priority given to railways as in Russia. The modal split in North Korea is as follows: railways $(70 \%)$, roads $(17 \%)$, sea $(10 \%)$ and air (3\%) (Roussin, 2015). However, railways were particularly affected by the economic crisis (Oh, 2001); the high electrification rate became a constraint in a context of energy scarcity, while only $7 \%$ of roads were paved (Bang, 2004). The road network, costlier to maintain and less well adapted to the transport of raw materials $(80 \%$ of transported products according to Tsuji, 2005), remains strictly controlled by the government through inspection tolls between main cities and provinces. Train and truck accidents were frequently reported (Cotton, 1996), aggravated by the rarity of signals, gas stations, and the poor condition of tracks and roads. The deepening crisis reinforced the influence of elevation and climate (Roussin, 2015), harming smooth domestic transport connectivity and concentrating traffic within Pyongan province, while $80 \%$ of North Korea's exports passed through Sinuiju at the Chinese border (Tsuji, 2005). Eastern regions, by contrast, declined rapidly (Pons, 2004).

The respective evolution of North Korea's international trade and maritime traffic, however, exhibit a widening gap (Figure 21.5), mainly due to increased cross-border trade with China, which occurred inland. According to the Korea International Trade Association (KITA), nearly $91 \%$ of North Korea's products were exported to China in 2013, compared with $51 \%$ in 2003 , while Chinese investments in North Korea expanded from US\$ 1.12 million to US\$ 86.2 million between 2003 and 2013. Some experts reported a steady increase of trade between 
North Korea and Dandong between 2000 and 2008 (Lee, 2009), as Dandong's exports to North Korea tripled and its imports from North Korea increased tenfold. Overall, border trade with China represented about one-third (32\%) on average of North Korea's total trade with China, and 9\% on average of North Korea's total foreign trade in 1997-2005 (Kim, 2001). In 2011, coal was being shipped from North to South China through the port of Rajin, while in the late 2000s the Chinese government announced the restart of the Changchun-JilinTumen project as a pilot economic zone and obtained a 50-year concession for operating a port terminal in Rajin in 2010, the two other terminals being operated by Russia and North Korea, respectively. Cross-border trade thus experienced steady growth, especially with Shandong, Hebei and Jiangsu provinces, which altogether reached $50 \%$ of the total (Kim, 2014). In 2012, just over 87 percent of both North Korea's exports and imports were with China, which is indicative of its growing dependency. Nearly 90 percent of trade between China and North Korea was with the six provinces, of which $42.7 \%$ with Liaoning and $32.3 \%$ for Shandong, Hebei, and Jiangsu. The Jilin province witnessed a Gross Regional Domestic Product (GRDP) growth rate of $13.4 \%$ in 2012, more than China's own GDP growth rate (Kim, 2014).

[Figure 21.5]

Another approach has been to estimate the importance of maritime transport in total foreign trade (Figure 21.6). We estimated the value of maritime flows by converting deadweight tons (dwt) into dollars based on US\$250 per ton (Ducruet and Jo, 2008), which was the average dwt-dollar ratio for Japanese and South Korean trade with North Korea in the 2000s. Results were compared with a weighted figure based on the estimation of value differentials among traffic types. As a result, the two ratios give a very different importance to maritime trade, with average shares of $19.2 \%$ for unweighted traffic and $11.1 \%$ for weighted traffic during the period. In fact, unweighted figures overestimate the importance of maritime transport mainly due to the high volume and low value of bulks. The observed evolutions show that North Korean trade was much less dependent on maritime flows in the recent period (2002-2014), with 4.3\% on average compared with 16.3\% for 1985-2001. 1991 registered an exceptional peak that can only be explained by the Rajin-Seonbong initiative, which mainly used the port during the construction and starting phases of the economic zone project (Jo and Ducruet, 2007). Another factor was the dramatic decline of shipping with Japan since 2002 (e.g. the Wonsan-Niigata ferry link). Lastly, maritime transport was mainly being used to carry lower-valued (but highly strategic) goods, such as oil or humanitarian aid, so that even in times of shipping growth in the recent period, the net value of shipping could not be reflected on account of its overall shrinking volume.

[Figure 21.6] 


\section{Overseas maritime connectivity}

\section{General trends}

North Korea's foreign trade used to be dominated by the Soviet Union, whose share surpassed $50 \%$ in 1960 , dropped to $25 \%$ in 1977 , and reverted to $50 \%$ around 1986 , while China's share gradually declined from $32 \%$ to $11 \%$ in the same period (Choi, 1992). Available statistics for trade with its main economic partners provided complementary results for the 1989-2014 period (Figure 21.7). Soviet Russia still occupied about $60 \%$ of total foreign trade in 1989-1990, and nearly disappeared in subsequent years (1\% in 2014), superseded by Japan and China. The "rest of the world", namely countries outside Northeast Asia, accounted for around $30 \%$ of total trade on average from the early 1990 s to the early 2000s, but went through a drastic drop since then, reaching only $11 \%$ in 2014 . This evolution confirms the shrinking of North Korea's long-distance economic ties, and greater concentration on its proximity, a key factor being the lack of oil to feed the economy. Japan officially ceased all trade with North Korea from 2009, after oscillating around $20 \%$ in the first half of the period. Conversely, South Korea's share rose rapidly since the 2000 s due to the thaw in inter-Korean ties. In general, North Korean imports and exports were based on humanitarian shipments, non-commercial exports (i.e. cooperation projects), material aid, but also commercial exports (e.g. machinery and transport equipment, textile and chemicals, electric and electronic products ( $80 \%$ to $90 \%$ ), while its exports to South Korea increased regularly after 2002 - mainly textiles, metals, agricultural and fish products. However, an escalation of tensions from both sides caused the reduction of South Korea's share to the advantage of China, mainly based on inland border trade, as discussed above.

[Figure 21.7]

A similar but fuller picture is provided by vessel movement data. A major factor has been the drastic decline of Japan's share, from about $80 \%$ to negligible amounts in recent years (despite its official trade interruption with North Korea). A similar decline occurred for Hong Kong, despite a slight recovery to roughly $15 \%$ in 2011-2012. As for trade values, major changes concern South Korea and China. The latter had even become dominant in the last two years under study, culminating in around $73-78 \%$ of total traffic, reflecting its role as North Korea's dominant trading partner. While the respective shares of China and South Korea had been relatively even in the early period, China's share was superior to South Korea's share between 1986 and 1998, namely before North Korea's reforms. From 19992000 South Korea became North Korea's largest maritime partner for eight consecutive years (2003-2010), reaching peaks of $74 \%, 80 \%$, and $81 \%$ in $2008-2010$. This is somewhat 
counterintuitive, given the worsening of North-South political relationships from 2007 onwards and reinforced tensions around the Northern Limit Line (Gelézeau, 2007). Growing trade with China and uneven North-South relationships caused a rapid decline of South Korea's share, which fell to 20-30\% in 2011-2013, and to only 9\% and 6\% in 2014 and 2015, respectively, i.e. the same share as in the late 1970s. Lastly, an interesting element is the share of domestic shipping, which fell from an average of $12 \%$ in the period $1985-1995$ to $9 \%$ in 1996-2007 and only slightly more than $1 \%$ in the rest of the period. This indicates that domestic (or coastal) shipping was not used to palliate the deficiencies of the land-based transport system and logistics. Because coastal shipping is more likely to occur between East coast ports, its decline might also relate to the deliquescence of such cities, which are mostly connected by long-distance shipping bringing external aid.

\section{Inter-Korean maritime flows}

Official statistics provided by the Ministry of Unification in South Korea (2015) do not detail the modal split of inter-Korean trade and exchanges. Older statistics had underlined that inter-Korean maritime trade reached 15.7 million tons in 2006, a 240\% growth rate compared with 2005, while the amount of vessels crossing the Korean border doubled between 2004 and 2005, following the 2004 inter-Korean maritime agreement, but this number has greatly reduced since then. Thus, the precise geographic distribution of interKorean maritime flows remains unknown. Absolute tonnage between North and South has been somewhat irregular: almost non-existent until the mid-1980s, moderate between 1989 and 1998, relatively strong between 1999 and 2010 (with a peak in 2005), and returning to low values since 2011 . South Korea's share eventually reached $68 \%$ in 2008 , after regular growth since 1996, echoing earlier works that described this process as North Korea's growing "hub dependence" on South Korea (Ducruet, 2008).

Mapping shipping flows across the Korean peninsula provides a clear picture of such an evolution (Figure 21.8). In the early phase of the period under study, inter-Korean flows shifted from almost non-existent to a concentration along the East coast between Wonsan and Ulsan principally (followed by Busan), all of which specialized in liquid bulks (oil and chemicals). Growing traffic became visible at Heungnam and Cheongjin to connect Busan, while Nampo and Incheon were also increasingly connected. We also see that East and West coasts were mainly connected through Busan and Incheon. That was followed by a multiplication of North-South linkages, with a marked increase in the number of connected ports.

Traffic had concentrated mainly along the West coast, with a shift from the Nampo-Busan line to the Nampo-Incheon line, followed in 2004-2006 by Haeju and Pyeongtaek, to absorb 
the growing traffic near the two country's capital cities. Shipping a container between Incheon and Nampo once cost as much as US\$1,000 for 24h and a distance of only 100 kilometers, as much as the cost to reach Europe (Ahn, 2001). Later, operated by South Korean companies such as Hansung Shipping ( $90 \%$ of inter-Korean maritime flows), which exported South Korean textiles and imported North Korean raw materials for Samsung, LG, and Daewoo (Kim, 2004). Kook Yang Shipping was also involved on the Incheon-Nampo line to support further container traffic and weekly ferry shuttles, which would reduce the cost to US\$ 750 (Korea Times, 2001; Ahn, 2002). In the more recent period, the Nampo-Incheon line maintained its importance, notwithstanding a drastic decline of all traffic (2010-2012).

On the East coast, Cheongjin and Heungnam remained the central nodes, connected primarily with Ulsan and Busan, while Wonsan began to lose ground gradually. In the last phase, the Incheon-Nampo linkage had nearly disappeared, replaced by new lines between secondary ports, such as Rajin, Daesan, Pyeongtaek, Boryoung, Donghae, and Pyongyang. Overall, North-South maritime dynamics were quite irregular, not only in traffic volumes, but also in terms of spatial distribution, with important shifts from one coast to the other, and between large and small ports. Recent figures corroborate certain press releases about plans to use Rajin as an inter-Korean hub, echoing earlier plans for Heungnam (Joongang Daily, 2006).

[Figure 21.8]

\section{North Korea-China maritime flows}

The overwhelming importance of China in North Korea's recent foreign trade is worth analysing on a longer-term basis, notably for a comparison with inter-Korean shipping dynamics. Although most of the border trade of any value between China and North Korea occurs by land, on average $85 \%$ of its tonnage was transported by sea in the recent decade (Table 21.1). While the number of vessel crossings quadrupled between 2001 and 2013 and tonnage nearly doubled, it is only from 2009 that China has surpassed South Korea in this area.

[Table 21.1]

Maritime linkages have experienced very distinct patterns over time since the early 1980s (Figure 21.9). One recurrent configuration is North Korea's reliance on the Hong Kong hub, a good indicator of long-distance shipping connecting regions such as the Black Sea and Europe. However, this link had become secondary in the late 1990s and has nearly disappeared since the 2000s, in line with South Korea's emerging role as North Korea's main transit hub. One exception is 2010-2012, when Hong Kong remained the only major link, just 
before South Korea lost its prominence in this network. Another stable feature has been the overarching importance of Nampo for shipping to and from China, mainly due to its geographic proximity (Yellow Sea) and gateway function for Pyongyang. Mainland Chinese connections have shifted hugely over time and space. Dalian is one of the major Chinese hubs, especially in the early period, mainly for containers. Other hubs have emerged, such as Rizhao and Dandong, to receive iron ore and coal from North Korea. The fact that bulk products are the main flow largely explains why Shanghai and Shenzhen, China's main container ports, are underrepresented in the figure.

In the late period, a major driving force for reinforced shipping flows is the rapid increase of North Korea's coal exports to China (Vitelli, 2015), thereby becoming the latter's primary supplier after Australia and Indonesia. Although it was recently reported that the Russian port of Zarubino was preferred to Rajin for developing further Chinese (but also Russian and Mongolian) transit trade with the Pacific (Asia Cargo News, 2014), Rajin appears as a very central hub in the latest period, developing strong links with the coal-dependent region of Southern China (Wang and Ducruet, 2014). One favourable factor is Rajin's wide and standard railway gauge, offering easy and cheap access of Russian coal to the port, making it more attractive than Zarubino (Hong et al., 2014). The Russian railway company RDZ even sold part of Rajin port's concession rights on the third pier to a South Korean consortium (POSCO, Hyundai Merchant Marine, and Korea Railway) for shipping coal to Pohang, Gandjin and Gwangyang (2013-2015), but nuclear tests in early 2016 interrupted the process.

[Figure 21.9]

\section{Conclusion}

Overall, this research has shed new light on the maritime dynamics of one of the most unknown countries in the world. In turn, the analysis of maritime traffic evolution over 39 years reveals interesting features that help to document and understand the economic and political issues at stake in North Korea. Accessing such untapped and first-hand statistics has been the only way to palliate the inadequate, approximate and outdated nature of other data on transport, logistics, and shipping in North Korea.

This analysis of data provided many clues about the long-term and short-term maritime dynamics affecting North Korean ports and their linkages with the outside world. On a daily, monthly or yearly basis, North Korea's maritime activity had been growing until the 1980s and has been on the decline since then, except for certain peaks largely attributable to humanitarian aid, at least for the early 2000s. This decline was at variance with growing 
foreign trade, leading to a high dependency on land-based freight flows (road, rail) with China. A rapid shrinkage of North Korea's forelands occurred in parallel with an ageing, considerably smaller and increasingly immobile North Korean fleet. Foreign vessels remained dominant to ensure the future of North Korean shipping and raising questions regarding the isolated reputation of a country which could not rely on its own ships. Drastic traffic shifts occurred within Northeast Asia, from Japan to South Korea and then China, reflecting wider trade patterns, i.e. from who are North Korea's oil and food needs fulfilled.

This research can be considered as an introduction to the potential offered by shipping data for the investigation of North Korea's changing economic and trading dynamics and linkages. This has enormous implications in terms of security and cargo tracking for organisations concerned with under-embargo trade. Further research will consider carrying out a survey of ship operators visiting North Korean ports, based on the identity of ship operators. For academic research, this chapter may well contribute to a better understanding of how a major crisis affects shipping network design and spatial distribution.

\section{Acknowledgements}

The authors would like to thank Dr. Sungjun Park, Korea Maritime Institute, for his useful comments, and Dr. Chengjin Wang, Chinese Academy of Sciences, for sharing Chinese crossborder data. The research leading to these results has received funding from the European Research Council under the European Union's Seventh Framework Programme (FP/20072013) / ERC Grant Agreement n. [313847] "World Seastems".

\section{References}

Ahn C.Y. (2003) North Korea Development Report 2002/3. Seoul: Korea Institute for Economic Policy.

Ahn M.B. (2002) Restoration of the Seoul-Sinuiju line: review and outlook. East Asian Review, 14(1): 107-119.

Ahn M.Y. (2001) Slow boat to North Korea. Cargo News Asia, May 7.

Bang H.K. (2004) Research notes: towards an integrated logistics system in Northeast Asia. East Asian Review, 16(2): 111-121.

Choi E.K., Kim E.H., Merill Y.S. (2003) North Korea in the World Economy. London \& New York: Routledge. 
Choi S.Y. (1992) Foreign trade of North Korea: 1946-1988. Unpublished PhD dissertation, Northern University.

Cotton J. (1996) China and Tumen river cooperation: Jilin's coastal development strategy. Asian Survey, 36: 1086-1101.

Ducruet C. (2008) Hub dependence in constrained economies: The case of North Korea. Maritime Policy and Management, 35(4): 374-388.

Ducruet C., Jo J.C. (2008) Coastal cities, port activities and logistics constraints in a socialist developing country: The case of North Korea. Transport Reviews, 28(1): 1-25.

Ducruet C., Roussin S., Jo J.C. (2009) Political and economic factors in the evolution of North Korea's maritime connections. Journal of International Logistics and Trade, 7(1): 1-23.

Forster-Carter A. (2001) The shipping forecast: choppy waters. Asia Times, 15 February.

Gelézeau V. (2007) An island as interface: critical position of paengnyŏn-do in the Korean border region. Association for Korean Studies in Europe, Conference Proceedings, Dourdan, April 16-21.

Hong S.G., Lee S.W., Park S.J. (2014) International cooperation and the logistics market in Northeast Asia: problems and prospects for North Korea. North Korean Review, 10: 39-55.

Jo J.C., Adler S. (2002) Planning in the socialist developing country: the case of North Korea. Habitat International, 26: 251-267.

Jo J.C., Ducruet C. (2006) Maritime trade and port evolution in a socialist developing country: Nampo, gateway of North Korea. The Korea Spatial Planning Review, 51: 3-24.

Jo J.C., Ducruet C. (2007) Rajin-Seonbong, new gateway of Northeast Asia. Annals of Regional Science, 41(4): 927-950.

Joongang Daily (2006) North eyes inter-Korean port in the East. June 14.

Kim C.W. (2014) Open North Korea: Economic Benefits to China from the Distance Effect in Trade. Issue Brief, ASAN Institute for Policy Studies.

Kim I.S. (2001) The Rajin-Sonbong economic and trade zone (RSETZ): the sources of difficulties and lessons for the future. In: Yoon C.H., Lau L.J. (Eds.), North Korea in Transition, Cheltenham and Northampton: Edward Elgar, pp. 301-333.

Kim S. (2004) Inter-Korean Relations: Problems and Prospects. Basingstoke: Palgrave Macmillan.

Kim W.B. (2001) Planning issues in the territorial integration of the Korean peninsula. Geojournal, 53: 47-56.

Korea Times (2001) Inter-Korean processing trade set to resume. February 20. 
Lee C.J. (2005) Trade and Investment in North Korea. Seoul: Korea Institute for International Economic Policy.

Lee J.U. (2009) Analysis of Chinese companies' border trade with North Korea. World Economy, 9(26): Korea Institute for International Economic Policy.

Nanto D.K., Chanlett-Avery E. (2005) The North Korean economy: background and policy analysis. Report for Congress, Congressional Research Service, February 9.

Noland M. (2000) Avoiding the Apocalypse. The Future of the Two Koreas. Washington: Institute for International Economics.

Oh J.H. (2001) Strategies for developing transport infrastructure in North Korea, Yoon C.H., Lau L.J. (Eds.), North Korea in Transition, Cheltenham and Northampton: Edward Elgar, pp. 215-236.

Olsen J., Vannoni M., Koelm J. (2003) Maritime Cooperation for the Koreas. Sandia Working Paper $n^{\circ} 1843 p$, Albuquerque: Cooperative Monitoring Center.

Pons P. (2004) Fragile dégel en Corée du Nord. Le Monde, 16 December.

Roussin S. (2015) A brief journey in DPRK. A geo-economic approach. Seminar presentation, June 23.

Rozman G. (2004) Northeast Asia's Stunted Regionalism: Bilateral Distrust in the Shadow of Globalization. Cambridge: Cambridge University Press.

Smith H. (2009) North Korean shipping: a potential for WMD proliferation? East-West Center, Asia Pacific Issues No. 87.

Tsuji H. (2005) The Transport Infrastructure of the DPRK. Niigata: Economic Research Institute for Northeast Asia.

UNCTAD (2000) World seaborne trade continues growth in 1999. http://www.unctad.org

Vigarié A. (1995) La Mer et la Géostratégie des Nations. Paris: Economica.

Vitelli A. (2015) North Korea gains in China coal exports as Vietnam bows out. Bloomberg, July 20.

Wang C., Ducruet C. (2014) Transport corridors and regional balance in China: The case of coal trade and logistics. Journal of Transport Geography, 40: 3-16.

Yonhap News (2005) South Korea to develop North Korean port of Nampo. January 4.

Yoon D.R., Babson B.O. (2002) Understanding North Korea's economic crisis. Asian Economic Papers, 1: 69-89. 


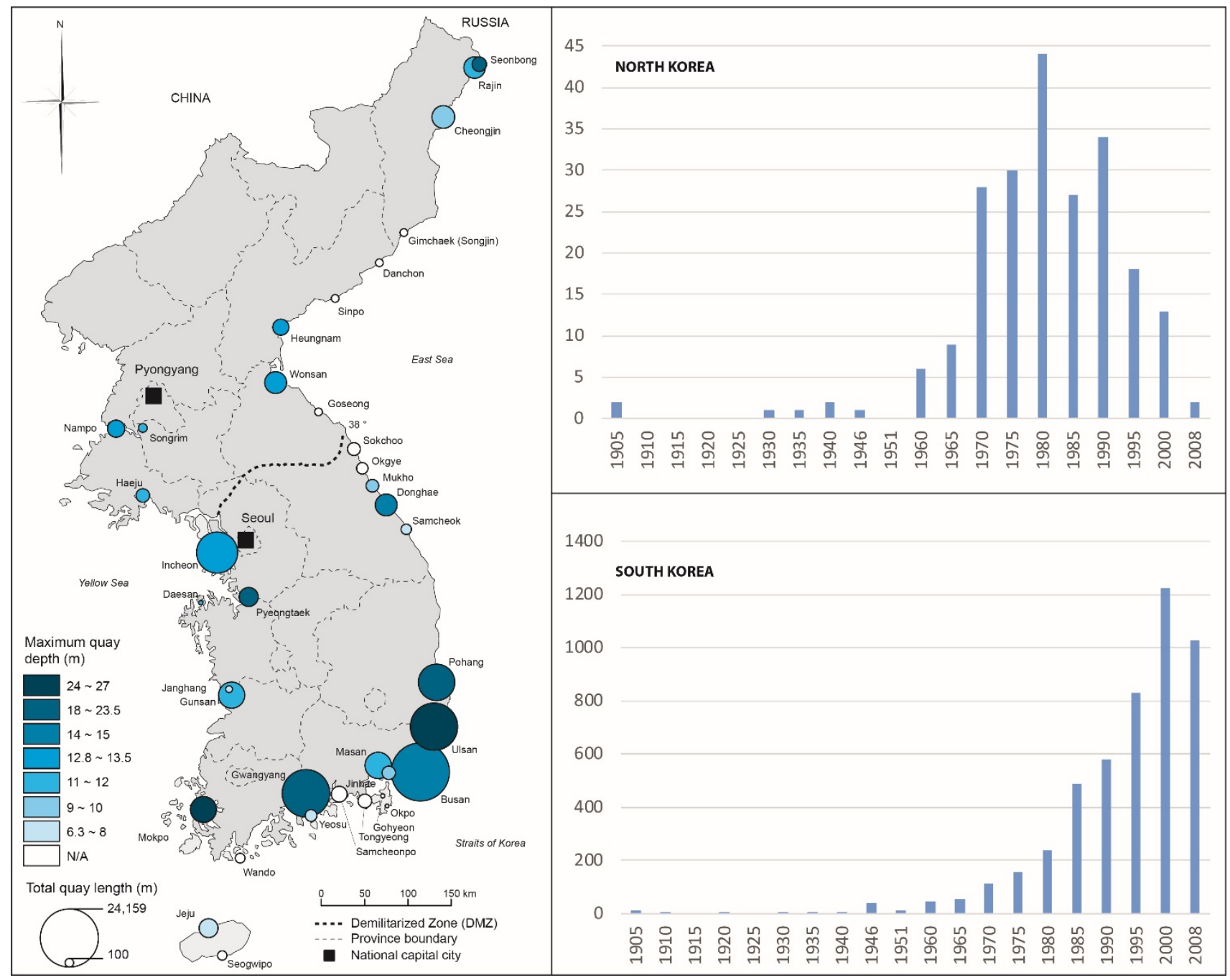

Figure 21.1: Infrastructures (2005) and vessel calls (1905-2008) at Korean ports

Source: own elaboration based on the Lloyd's Shipping Index and various sources 


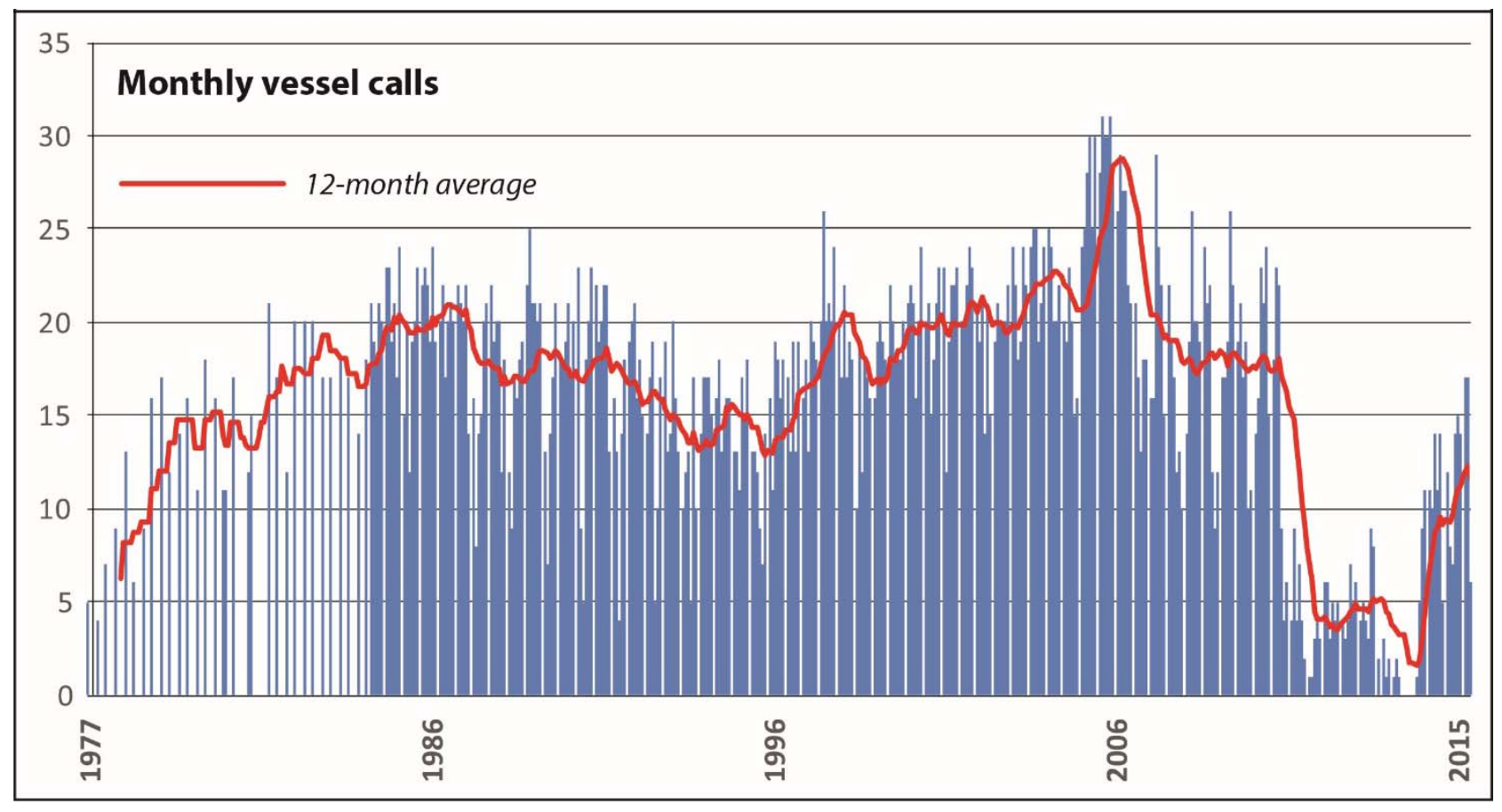

Figure 21.2: Monthly vessel traffic at North Korean ports, 1977-2015

Source: own elaboration based on LLI data 

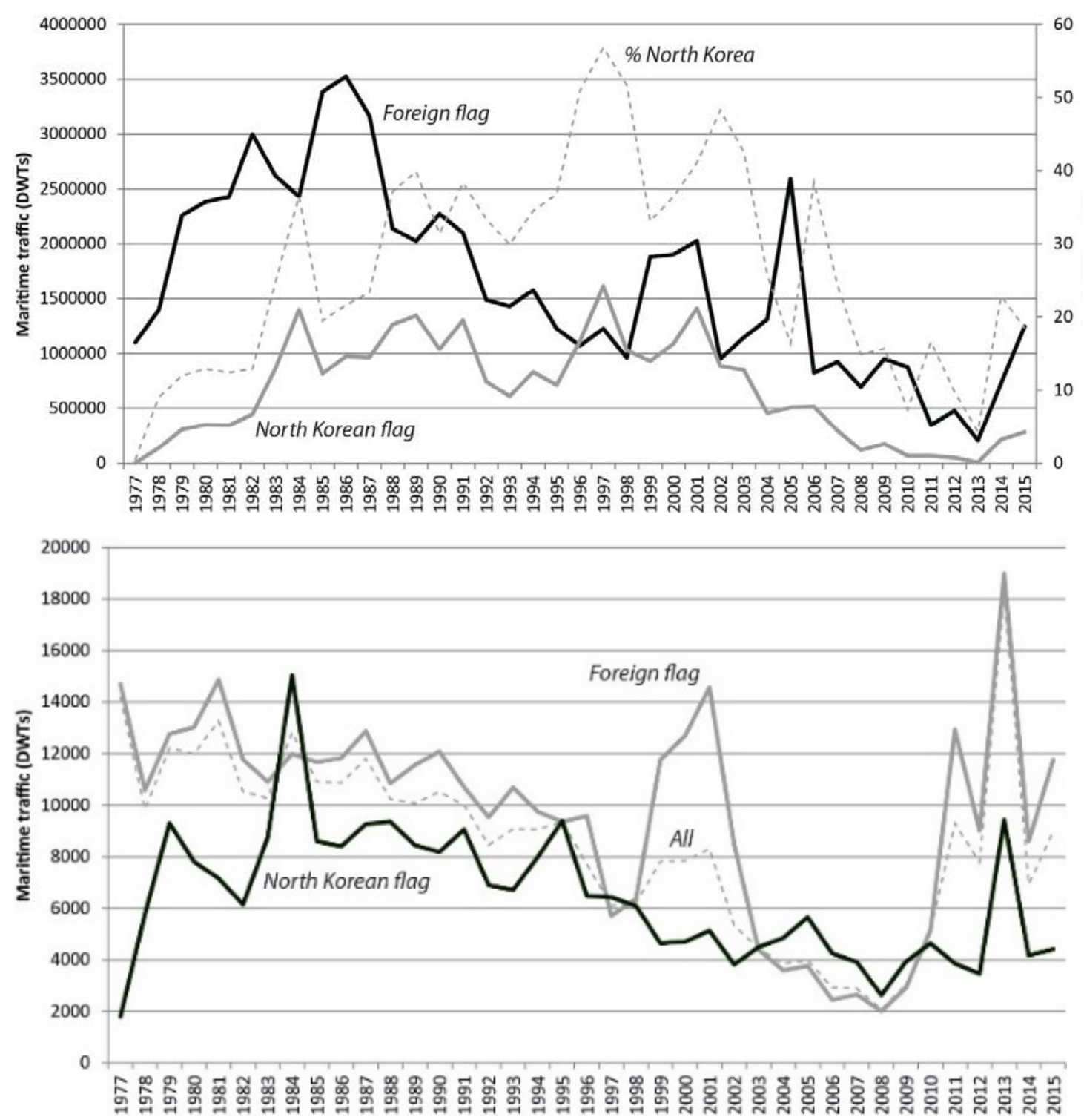

Figure 21.3: Total and average vessel traffic, North Korean and foreign flags (1977-2015)

Source: own elaboration based on LLI data 

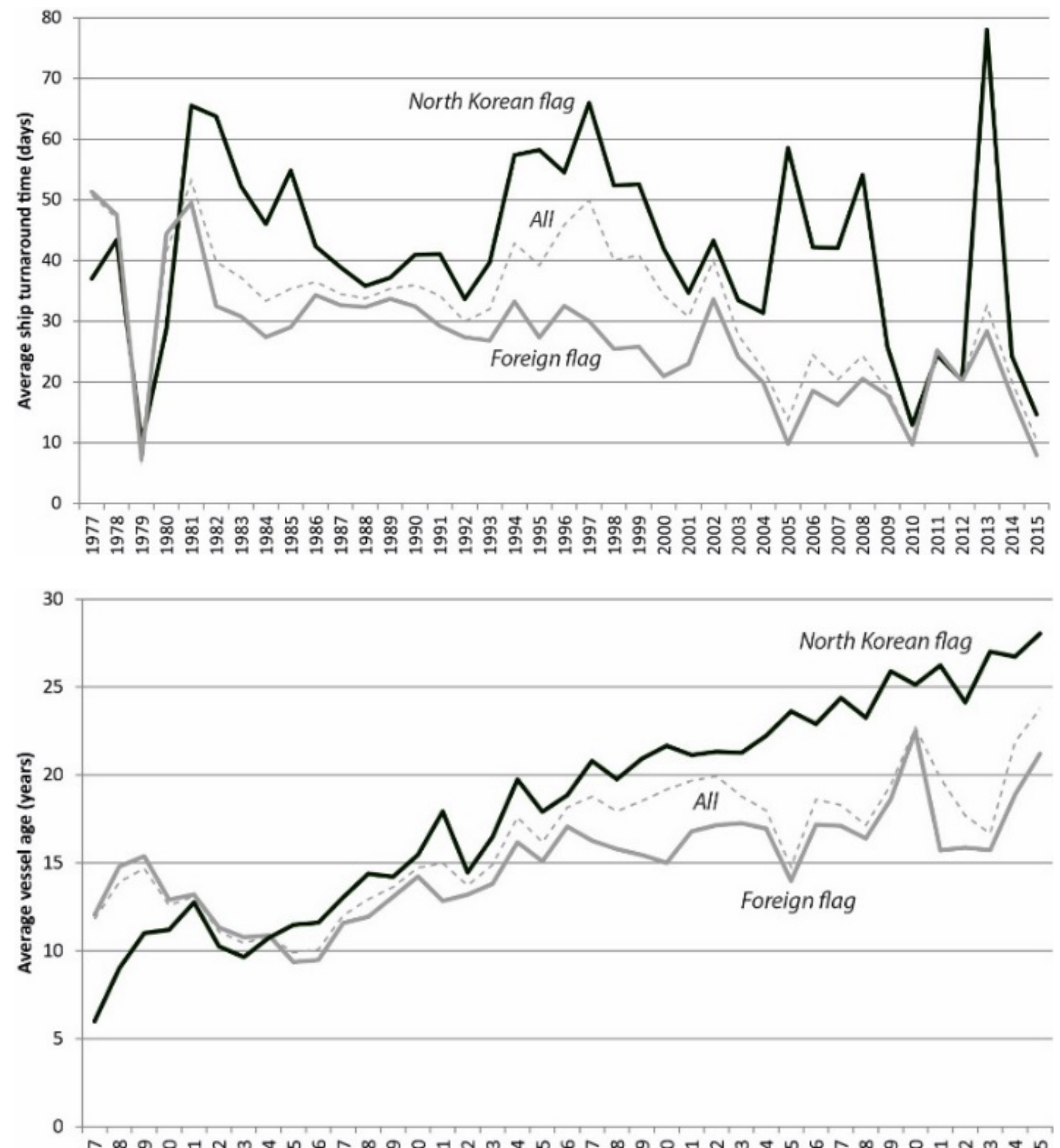

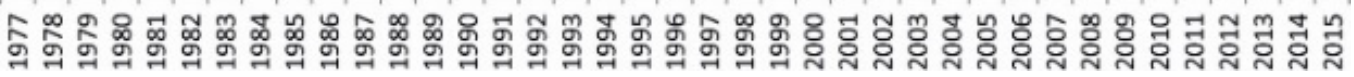

Figure 21.4: Average turnaround time and fleet age, North Korean and foreign flags (1977-2015)

Source: own elaboration based on LLI data 


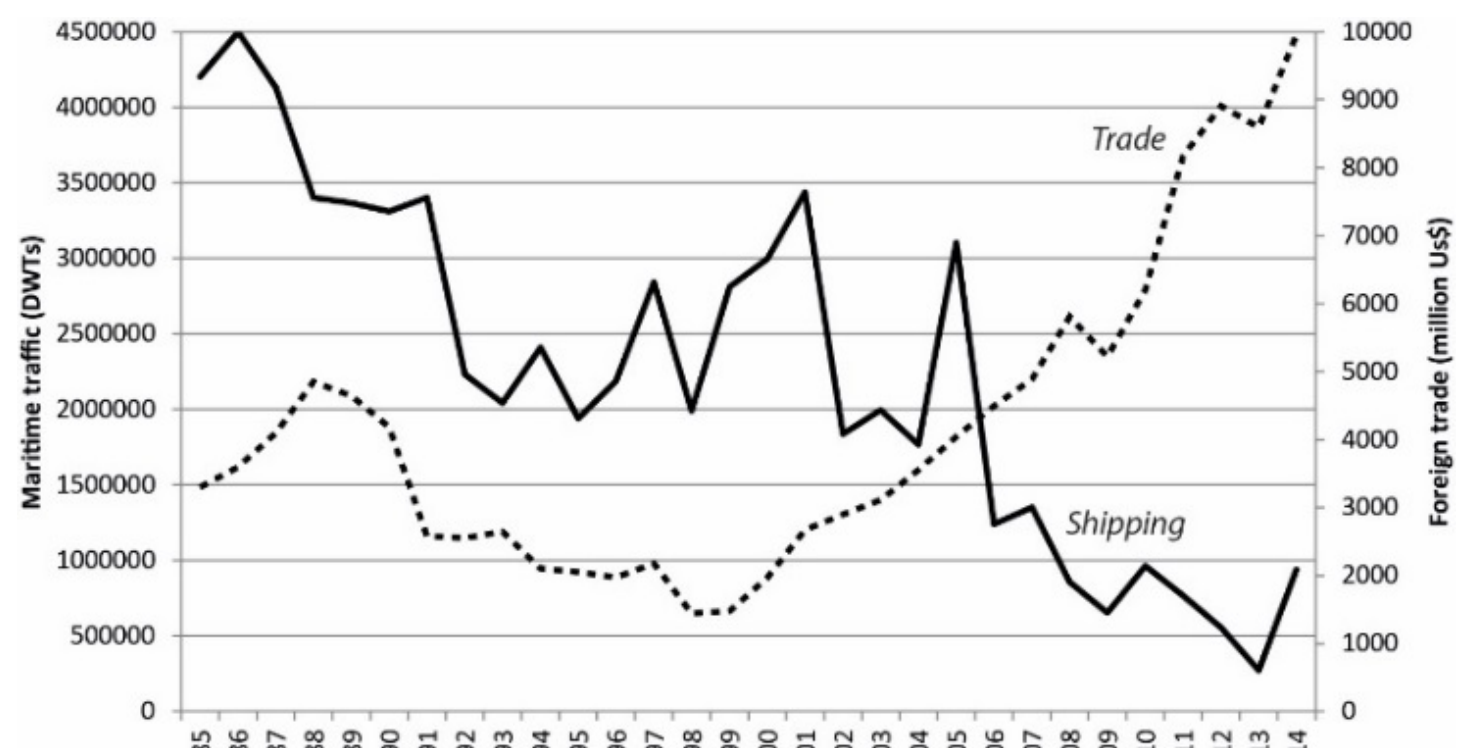

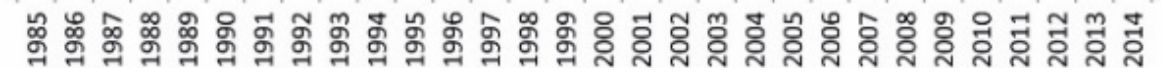

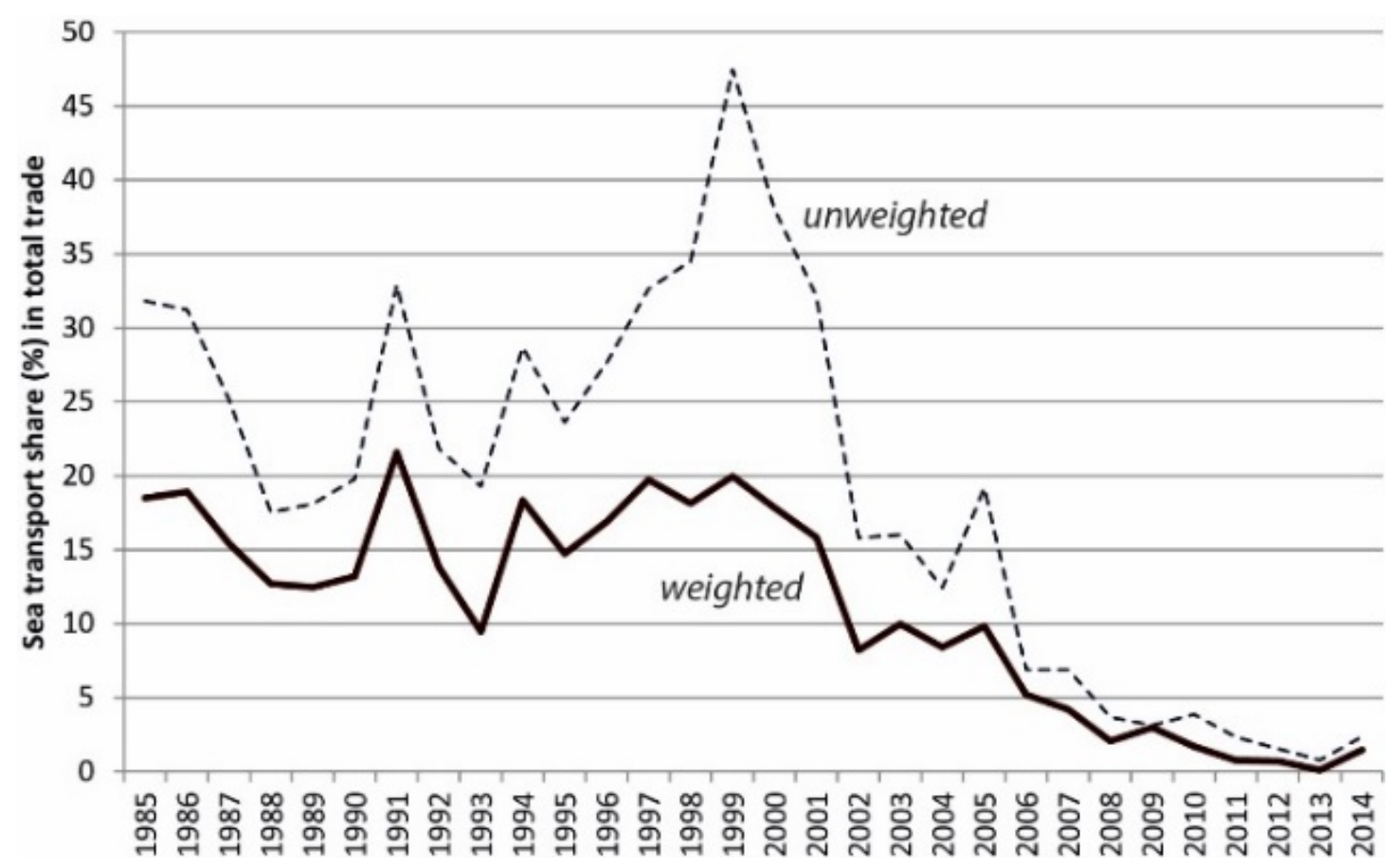

Figure 21.5: Trade and shipping evolution of North Korea, 1985-2014

Source: own elaboration based on LLI data and various trade data 

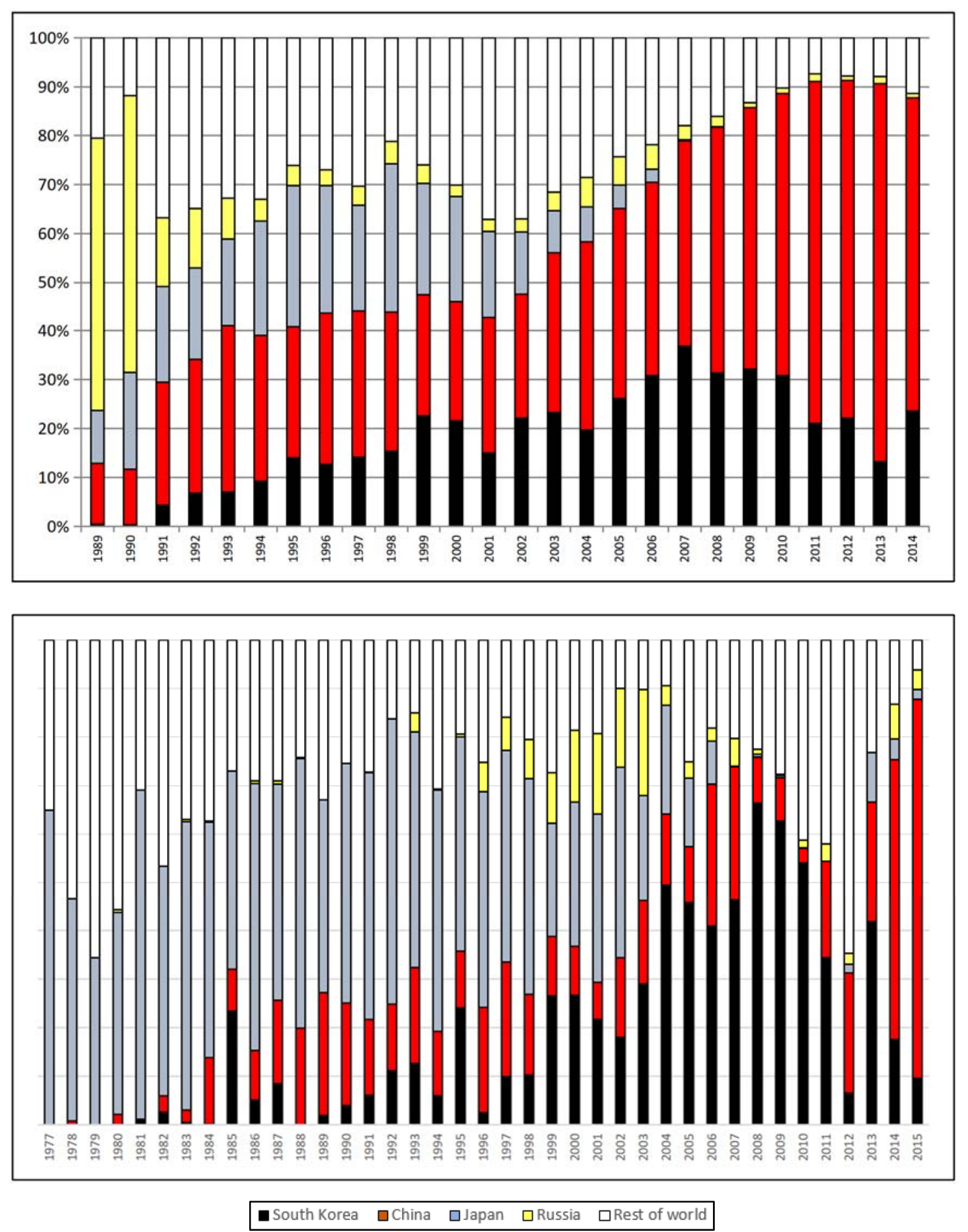

Figure 21.6: North Korea's overseas linkages in total foreign trade (top) and maritime traffic (bottom) Source: own elaboration based on Bank of Korea, KOTRA, and LLI data 

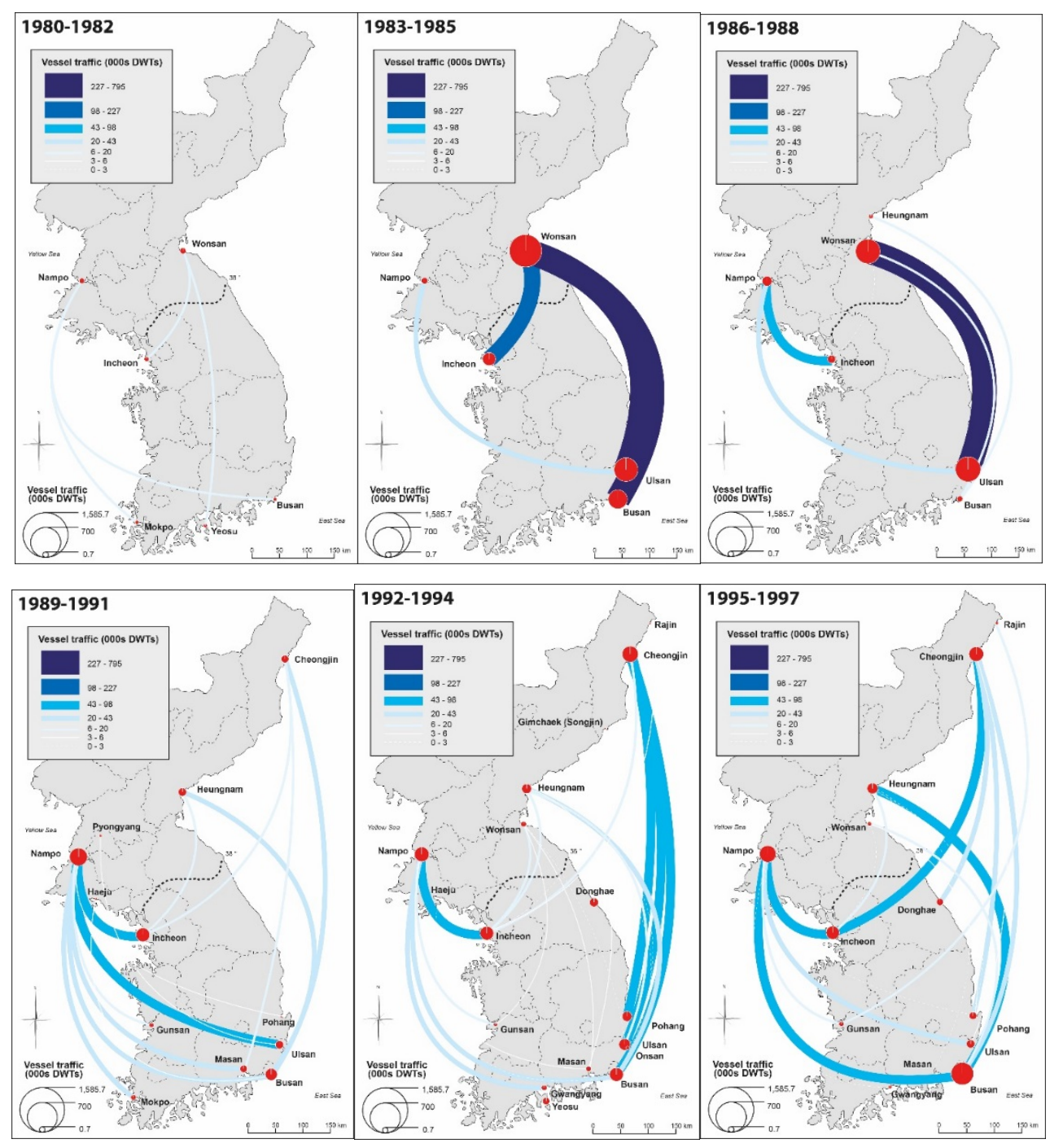

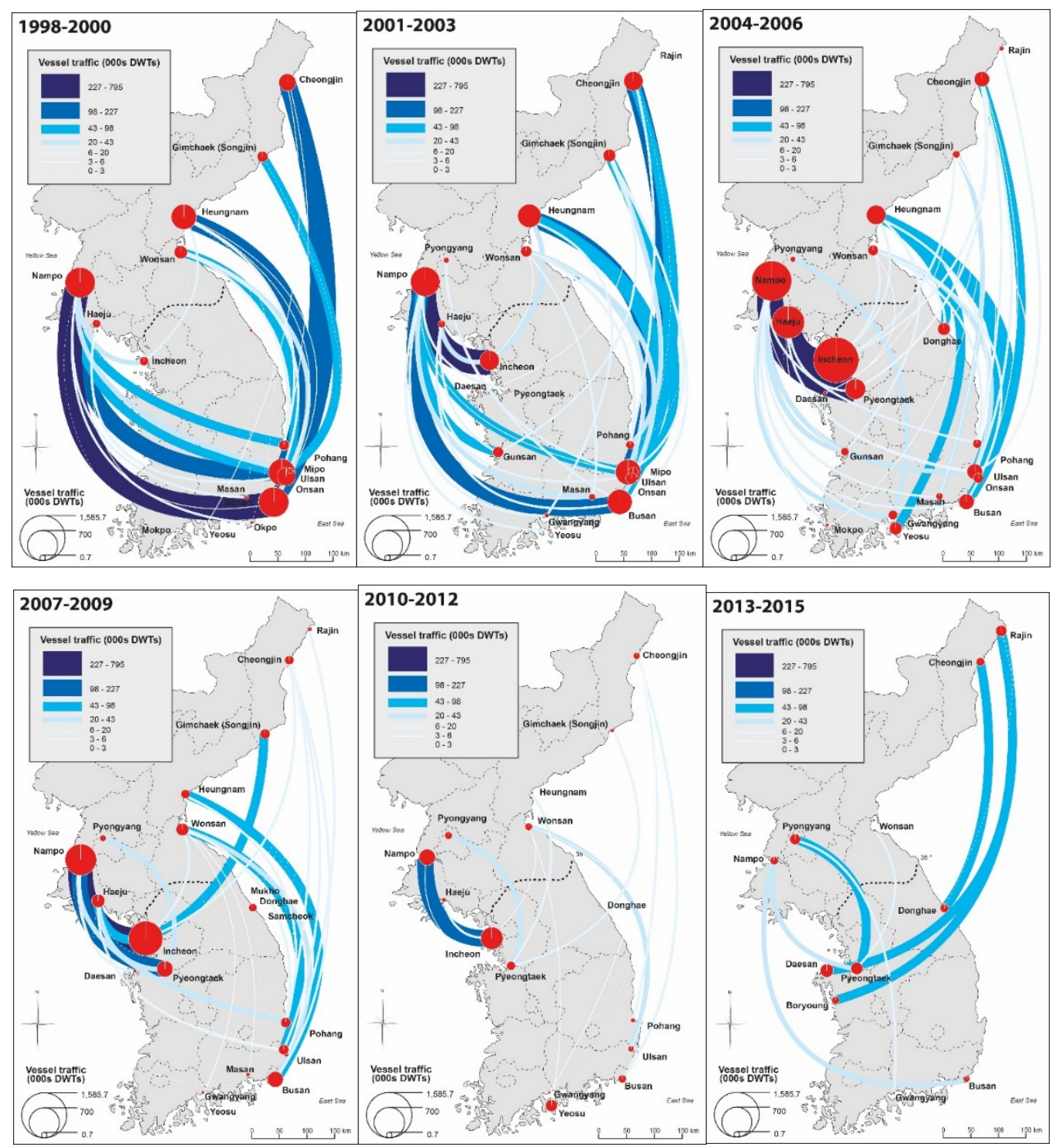

Figure 21.7: Inter-Korean maritime linkages, 1980-2015

Source: own elaboration based on LLI data 

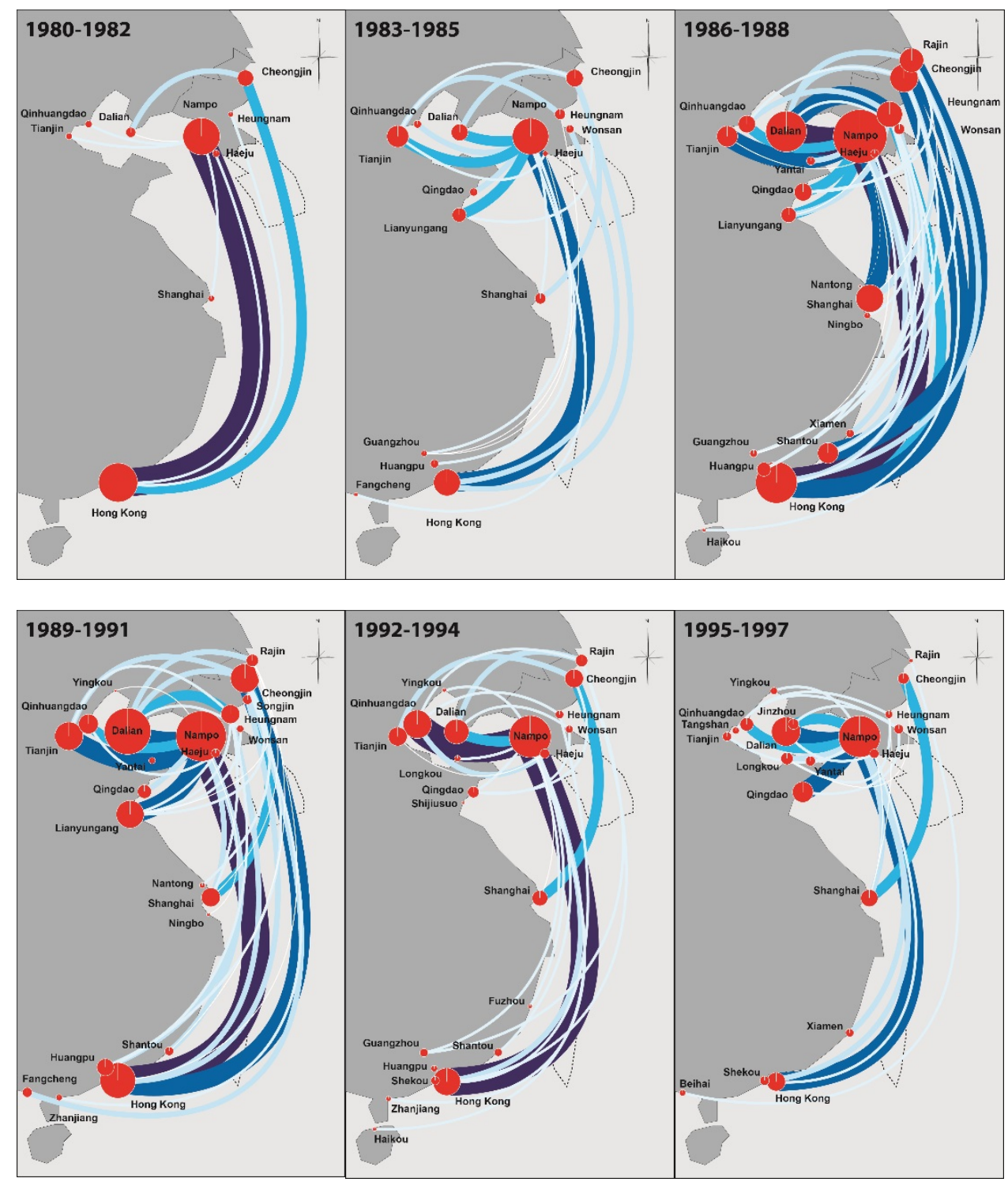

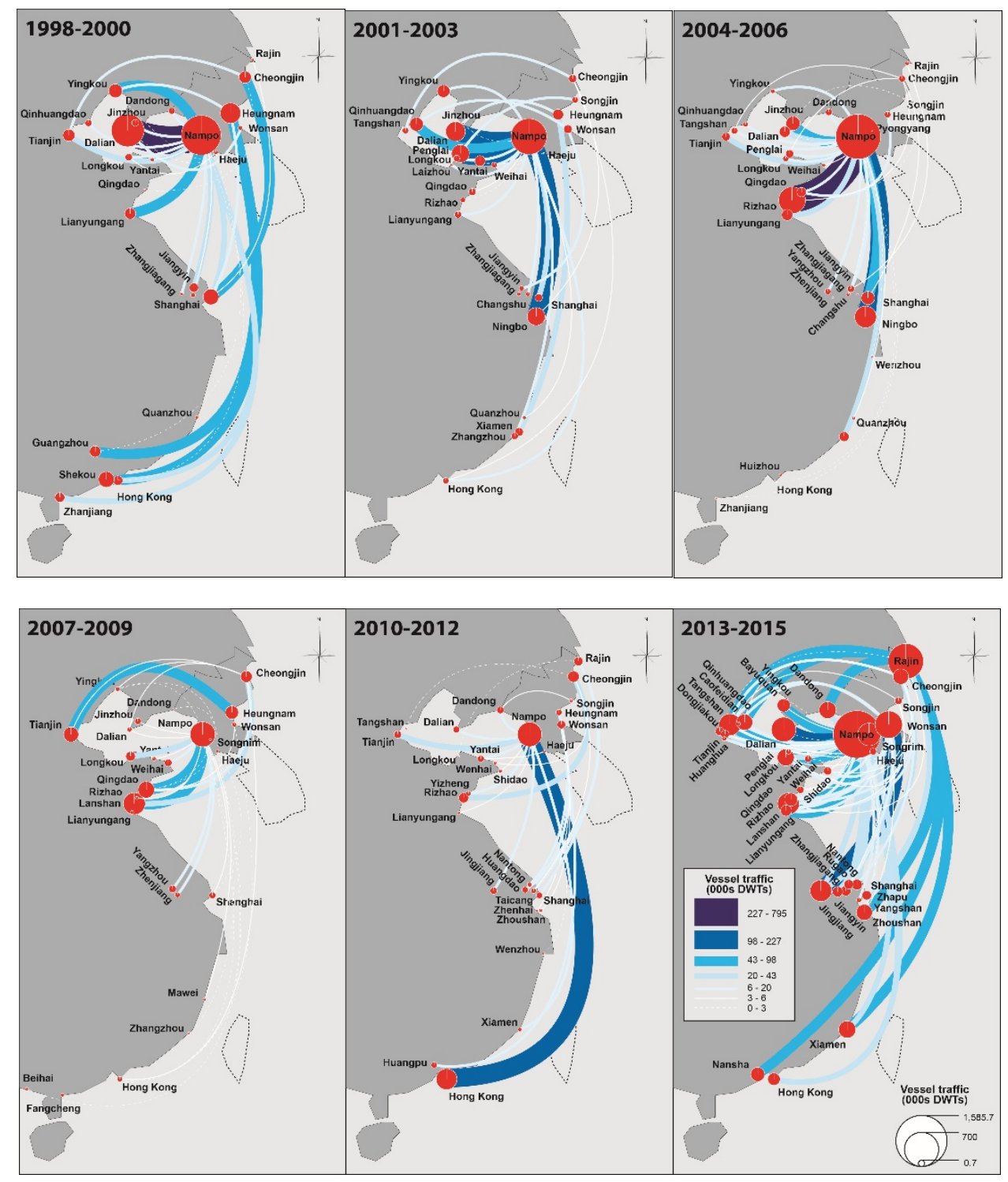

Figure 21.8: China-North Korea maritime linkages, 1980-2015

Source: own elaboration based on LLI data 


\begin{tabular}{|c|c|c|c|}
\hline \multirow{2}{*}{ Year } & \multicolumn{2}{|c|}{ China } & South Korea \\
\cline { 2 - 4 } & $\begin{array}{c}\text { Share in total cross- } \\
\text { border flows (\% tons) }\end{array}$ & \multicolumn{2}{c|}{ No. vessel crossings } \\
\hline 2013 & 82.7 & 4,457 & 31 \\
\hline 2012 & 86.7 & 3,496 & 228 \\
\hline 2011 & 82.7 & 4,916 & 142 \\
\hline 2010 & 86.9 & 4,399 & 1,432 \\
\hline 2009 & 87.1 & 2,664 & 2,577 \\
\hline 2008 & 87.6 & 3,774 & 7,435 \\
\hline 2007 & 91.5 & 3,383 & 11,891 \\
\hline 2006 & 87.7 & 2,531 & 8,401 \\
\hline 2005 & 87.6 & 2,613 & 4,497 \\
\hline 2004 & 86.4 & 2,127 & 2,124 \\
\hline 2003 & 74.7 & 1,383 & 2,022 \\
\hline 2002 & 78.0 & 1,166 & 1,827 \\
\hline 2001 & 88.8 & 1,032 & 1,686 \\
\hline
\end{tabular}

Table 21.1: Cross-border traffic between North Korea, China and South Korea (20012013)

Source: own elaboration based on Ministry of Unification in South Korea and China Statistical Yearbooks 